\title{
First record of Hypodematium squamuloso-pilosum Ching (Hypodematiaceae) from Korea
}

\author{
Chang Shook Lee*, Kanghyup Lee ${ }^{1}$ and Man Kyu Lee ${ }^{2}$ \\ Department of Science Education, Ewha Womans University, Seoul 03760, Korea \\ ${ }^{1}$ Korea National Arboretum, Pocheon 11186, Korea \\ ${ }^{2}$ Janghowon Elementary School, Icheon 17420, Korea \\ (Received 30 April 2017; Revised 15 June 2017; Accepted 20 June 2017)
}

\section{한반도 미기록 식물: 흰금털고사리(금털고사리과) \\ 이창숙* · 이강협 ${ }^{1} \cdot$ 이만규 $^{2}$ \\ 이화여자대학교 사범대학 과학교육과, ${ }^{1}$ 국립수목원, ${ }^{2}$ 장호원초등학교}

\begin{abstract}
A new unrecorded species, Hypodematium squamuloso-pilosum Ching (Hypodematiaceae), previously known only in China, was newly found on the rocks of a limestone mountain in Yeongwol-gun, Gangwondo, Korea. This taxon is distinguished from H. glanduloso-pilosum (Tagawa) Ohwi, reported as a species of Hypodematium in Korea based on linear lanceolate scales on the rhizome and a stipe base, white long hairs throughout the leaves, rarely reddish brown curly linear scales on the stipe, and oblong-lanceolate basal pinna. This taxon was most similar to $H$. hirsutum based on the plant height, rhizome, scale shape and size, sori position, and indusium shape. A new Korean name, 'Huin-geum-teol-go-sa-ri', was given based on the long white hair throughout. Descriptions and illustrations of this taxon and a photograph of its habitat are provided from Korea.
\end{abstract}

Keywords: Unrecorded species, Hypodematium squamuloso-pilosum, Hypodematiaceae

The genus Hypodematium Kunze was firstly recognized as four species, including one subspecies, by Iwatsuki (1964). It currently consists of 18 species distributed in rock crevices of limestone areas among mostly subtropical and warmtemperate regions of Asia and Africa, and 12-14 species are distributed in China (Shing et al., 1999; Zhang and Iwatsuki, 2013; Wang et al., 2014). This genus is well characterized by growth on limestone rocks, having short rhizome and swollen base of stipe densely covered with scales, stipes and laminae usually with acicular long hairs, mixed glandular hairs or glabrous, largest basal pinnae, and chromosome number $\mathrm{x}=41$ (Shing et al., 1999; Zhang and Iwatsuki, 2013; Wang et al., 2014). Opinions about the status of the genus Hypodematium were used differently by Dryopteridaceae (Loyal, 1960; Tryon and Tryon, 1982; Kramer et al., 1990;
Smith et al., 2006; Liu et al., 2007), Thelypteridaceae (Ching, 1963), and Athyriaceae (Pichi Sermolli, 1977). Hypodematiaceae firstly devised by Ching (1975) includes the genus Hypodematium as the majority genus (Wang et al., 2014), and this family is defined by one unique genus, Hypodematium, or three genera (Hypodematium, Didymochlaena, Leucostegia). It has been suggested that Hypodematiaceae is a monophyletic family based on molecular study (Christenhusz et al., 2011).

The genus Hypodematium in Korea was known to be distributed just one species, H. glanduloso-pilosum (Tagawa) Ohwi, with a simple species description (Park, 1975; Lee, 1980; Lee, 2006; Korea National Arboretum, 2008; Kim and Sun, 2015; Lee and Lee, 2015).

We identified an additional species, Hypodematium squamuloso-pilosum Ching, with about 100 individuals per

\footnotetext{
*Author for correspondence: ferncslee@hanmail.net
} 




Fig. 1. Illustrations of Hypodematium squamuloso-pilosum Ching, taken in a limestone forest at Yeongwol-gun, Gangwon-do, Korea, 24 Sep 2016. A. Sori and indusium in pinnules. B. Hairs in stipe. C. Habit. D. Scales in rhizome and stipe base. E. Sparse scales in stipe and rachis. F. Spore. G. White and long hairs.

$10 \mathrm{~m}^{2}$. It is reported as a newly recorded taxon from Korea and was collected from rocks of a limestone mountain in Yeongwol-gun, Gangwon-do. The local name was designated as 'Huin-geum-teol-go-sa-ri' based on its habitat. We compared and analyzed morphological characters between $H$. squamuloso-pilosum and similar interspecific taxa of Hypodematium to elucidate their taxonomic relationship. Morphological characters and illustrations of H. squamuloso-pilosum, along with photographs of the habitat, are newly reported to the species of Hypodematium from Korea.

\section{Taxonomic Treatment}

\section{Hypodematium squamuloso-pilosum Ching}

Korean name: Huin-geum-teol-go-sa-ri (흰금털고사리) (Figs. 1, 2).

Herbs, mostly rupestral, $12-30$ tall. Rhizomes shortly creeping, $1-2 \mathrm{~mm}$ in diameter, densely scaly; scales linear to narrowly lanceolate, $10-17 \times 1.0 \times 1.7 \mathrm{~mm}$, reddish brown, lustrous, membranous. Stipes $5-23 \mathrm{~cm}$ long, stramineous, densely scaly on swollen base, densely grayish white hairy, 


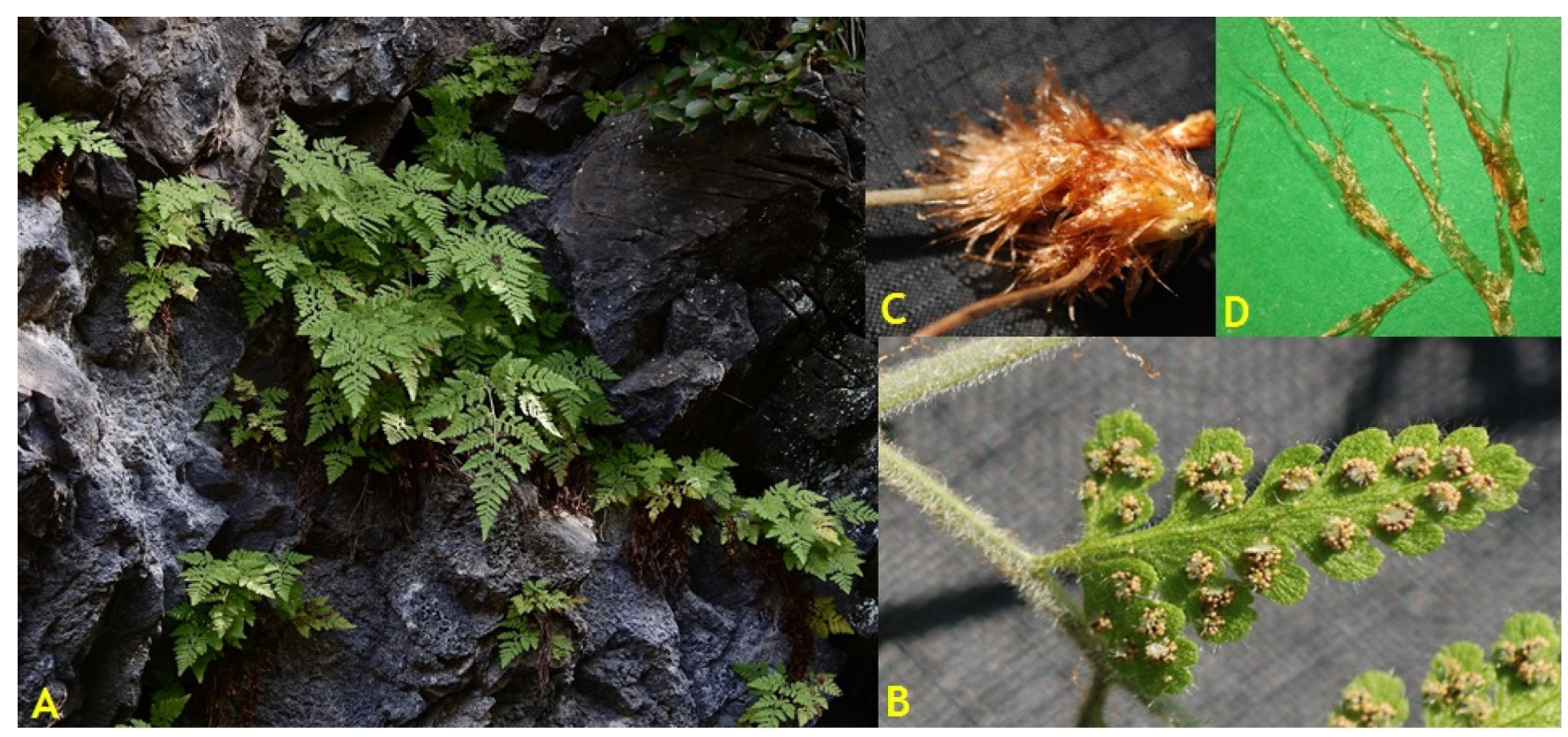

Fig. 2. Photographs of Hypodematium squamuloso-pilosum Ching, taken in a limestone forest at Yeongwol-gun, Gangwon-do, Korea, 24 Sep 2016. A. Habit. B. Indusia and sori in pinnule, and densely white long hairs in rachis and pinnule. C. Stipe base and rhizome covered with densely scales. D. Linear lanceolate scales in stipe base and rhizome.

Table 1. Comparative morphological characters between Hypodematium squamuloso-pilosum Ching, and related species distributed in China and Japan of Hypodematium (Iwatsuki, 1992; Wang et al., 2010; Zhang and Iwatsuki, 2013).

\begin{tabular}{|c|c|c|c|c|}
\hline Characters & H. squamuloso-pilosum & H. hirsutum & H. fordii & H. glanduloso-pilosum \\
\hline Plant height $(\mathrm{cm})$ & $12-30(-45)$ & $(23-) 35-60(-80)$ & $35-50$ & $12-56$ \\
\hline $\begin{array}{l}\text { Scales shape in rhizome } \\
\text { and stipe base }\end{array}$ & $\begin{array}{l}\text { Linear to narrowly } \\
\text { lanceolate }\end{array}$ & Linear-lanceolate & Narrowly lanceolate & Lanceolate \\
\hline Scales size $(\mathrm{mm})$ & $10-17 / 1.0-1.7$ & $10-15 / 1-1.3$ & $10-15 / 1.5$ & $10-15 / 1-3$ \\
\hline Stipe length $(\mathrm{cm})$ & $5-23$ & $(7-) 15-25(-40)$ & $15-20$ & $4-27$ \\
\hline $\begin{array}{l}\text { Hairs and scales } \\
\text { presence in stipe }\end{array}$ & $\begin{array}{l}\text { Long hairs throughout, } \\
\text { sometimes mixed with } \\
\text { glandular hairs and reddish } \\
\text { brown curly, linear scales }\end{array}$ & Glabrous upward & $\begin{array}{l}\text { Upward with sparse golden, } \\
\text { rod-shaped, } \\
\text { short glandular hairs }\end{array}$ & $\begin{array}{c}\text { Densely white short hairs \& } \\
\text { golden, } \\
\text { rod-shaped glands }\end{array}$ \\
\hline $\begin{array}{r}\text { Ratio of stipe } \\
\text { and lamina }\end{array}$ & $1-6 / 5$ & $3 / 4-5 / 7$ & 1 & $4 / 7-27 / 29$ \\
\hline $\begin{array}{l}\text { Hairs and scales } \\
\text { presence in lamina }\end{array}$ & $\begin{array}{l}\text { Long hairs all over, sparsely } \\
\text { reddish brown curly, } \\
\text { linear scales }\end{array}$ & $\begin{array}{l}\text { Both surfaces with sparsely } \\
\text { short grayish white hairs, } \\
\text { sometimes abaxially with } \\
\text { linear lanceolate scales on } \\
\text { costae and costules }\end{array}$ & $\begin{array}{l}\text { Both surfaces sparsely } \\
\text { golden glandular hairs, } \\
\text { densely on rachis, costae, } \\
\text { costules with glands }\end{array}$ & $\begin{array}{c}\text { Both surfaces sparsely hairy, } \\
\text { densely hairs and rod-shaped } \\
\text { glands along rachis, costae, } \\
\text { costules; sometimes mixed } \\
\text { with reddish brown linear } \\
\text { lanceolate scales }\end{array}$ \\
\hline Basal pinna shape & Oblong-lanceolate & Slightly oblique & Triangular-ovate & Ovate-oblong \\
\hline Basal pinnule shape & Oblong to ovate-oblong & Oblique & Oblong & Oblong \\
\hline Hairs in indusia & Densely hairs & Densely hairs & $\begin{array}{l}\text { Sparsely glandular hairs } \\
\text { especially along margins }\end{array}$ & $\begin{array}{c}\text { Densely hairs, usually with a } \\
\text { few glands }\end{array}$ \\
\hline Distribution & $\begin{array}{c}\text { Limestone crevices, Korea, } \\
\text { China }\end{array}$ & $\begin{array}{c}\text { Limestone crevices, China, } \\
\text { Bhutan, India, Myanmar, } \\
\text { Nepal }\end{array}$ & $\begin{array}{l}\text { Limestone crevices, } \\
\text { China, Japan }\end{array}$ & $\begin{array}{l}\text { Korea, C. China, Japan, } \\
\text { Thailand }\end{array}$ \\
\hline
\end{tabular}


rarely mixed with curly, linear scales at upward. Lamina 3-4 pinnatifid, ovate-oblong, base cordate, apex acuminate, herbaceous, $8-15 \times$ ca. $7-12 \mathrm{~cm}$, densely white long hairy on rachis and costae, sometimes mixed with glandular hairs and curly, linear, reddish brown scales. Pinnae 8-12 pairs, lower pairs $2-4 \mathrm{~cm}$ apart, basal pair almost opposite and largest, oblong lanceolate, apex shortly acuminate, $2-3$ pinnatifid, base cordate, $5-8 \times 2.5-3.5 \mathrm{~cm}$, basal pinnae shortly stalked. Pinnules 7-9 pairs, alternate, anadromous, shortly stalked, upper ones smaller, apex round or obtuse, margins serrate. Veins free, simple, ending at margin. Sori orbicular, 1-4 per segment, located on the middle of veinlets. Indusia reniform, persistent, almost entire or somewhat serrate at margin, densely covered with hairs.

Habitat: In rocks of limestone regions within forests.

Distribution: Yeongwol-gun, Gangwon-do, Korea.

Specimens examined: KOREA. Gangwon-do: Yeongwolgun, Hanbando-myeon, elev. 240 m, 24 Sep 2016, C.S. Lee \& $K$. Lee 16092401 (EWH [4 sheets], KH [3 sheets], KB [3 sheets]; 28 Oct 2013, K. Lee \& M.K. Lee 13102801 (KH [1 sheet]).

Taxonomic notes: The newly reported taxon in Korea, Hypodematium squamuloso-pilosum is known as an endemic in China (Zhang and Iwatski, 2013) but was found first in Gangwon-do in Korea.

The new local name 'Huin-geum-teol-go-sa-ri' was given based on its having throughout long white hairy. It was firstly found with Cornus walteri, Fraxinus rhynchophylla, Celtis koraiensis, Lespedeza maximowiczii, Ulmus davidiana var. japonica, Juniperus rigida, Aster scaber, and Commelina communis in a forest in Hanbando-myeon, Yeongwol-gun, Gangwon-do.

This taxon is distinguished from $\mathrm{H}$. glanduloso-pilosum (Tagawa) Ohwi reported as one species of Hypodematium in Korea based on scales in rhizome and stipe base linear to narrowly lanceolate, white long hairs throughout leaves, rarely reddish brown curly linear scales on stipe, and basal pinna oblong-lanceolate.

The chromosome numbers of $H$. squamuloso-pilosum and $H$. hirsutum have the same type as $n=41$ (41 II) based on cytotaxonomic study by Wang et al. (2014). This taxon firstly described from Korea was most similar with $H$. hirsutum distributed in China, Bhutan, India, Myanmar, and Nepal based on rhizome, scale shape and size, sori position, and hairs in indusia (Iwatsuki, 1992, 1995; Wang et al., 2010; Zhang and Iwatsuki, 2013) (Table 1). Hypodematium fordii distributed in China and Japan was also similar with H. squamuloso-pilosum, but the former has different characters from the latter based on almost glabrous upward in stipe, densely glandular hairs in lamina, triangular ovate basal pinna, and sparsely glandular hairs in indusia (Table 1).

Furthermore, it was distinguished from other taxa of the genus Hypodematium the distinct characters such as densely long hairs throughout the leaf and sparsely with glandular hairs and reddish brown curly linear scales, and basal pinna oblong lanceolate (Table 1).

\section{Literature Cited}

Ching, R.-C. 1963. A reclassification of the family Thelypteridaceae from the mainland of Asia. Acta Pytotaxonomica Sinica 8: 289-335.

Ching, R.-C. 1975. Two new fern families. Acta Phytotaxonomica Sinica 13: 96-98.

Christenhusz, M. J. M., X.-C. Zhang and H. Schneider. 2011. A linear sequence of extant families and genera of lycophytes and ferns. Phytotaxa 19: 7-54.

Iwatsuki, K. 1964. On Hypodematium Kuntz. Acta Phytotaxonomica et Geobotanica 21: 43-54.

Iwatsuki, K. 1992. Ferns and Fern Allies of Japan. Heibonsha Ltd., Tokyo, 311 pp. (in Japanese)

Iwatsuki, K. 1995. Hypodematium. In Flora of Japan I. Iwatsuki, K., T. Yamazaki, D. E. Boufford and H. Ohba (eds.), Kodansha Ltd., Tokyo. Pp 198-199.

Kim, C. H. and B.-Y. Sun. 2015. Hypodematiaceae. In Flora of Korea. Flora of Korea Editorial Committee (ed.), National Institute of Biological Resources, Incheon and Ministry of Environment, Seoul. P. 117.

Korea National Arboretum. 2008. Illustrated Pteridophytes of Korea. Korea National Arboretum, Pocheon, 547 pp. (in Korean)

Kramer, K. U., R. E. Holttum, R. C. Moran and A. R. Smith. 1990. Dryopteridaceae. In The Families and Genera of Vascular Plants. I. Pteridophytes and Gymnosperms. Kramer, K. U. and P. S. Green (eds.), Springer-Verlag, Berlin. Pp. 101-144.

Lee, C. S. and K. H. Lee. 2015. Pteridophytes of Korea: Lycophytes and Ferns. Geobook, Seoul, 471 pp. (in Korean)

Lee, T. B. 1980. Illustrated Flora of Korea. Hyangmunsa, Seoul. P. 22 (in Korean)

Lee, Y. N. 2006. New flora of Korea I. Kyohaksa Publ. Co., Seoul, 975 pp. (in Korean)

Liu, H.-M., X.-C. Zhang, W. Wang, Y.-L. Qiu and Z.-D. Chen. 2007. Molecular phylogeny of the fern family Dryopteridaceae inferred from chloroplast $r b c \mathrm{~L}$ and $a t p \mathrm{~B}$ genes. International Journal of Plant Sciences 168: 1311-1323.

Loyal, D. S. 1960. Some observations on the gametophyte of Hypodematium crenatum (Frosk.) Kuhn with a note on the 
phyletic affinities of the genus. Journal of the Indian Botanical Society 39: 133-139.

Park, M. K. 1975. Illustrated Encyclopedia of Fauna and Flora of Korea. Vol. 16. Pteridophyta. Ministry of Education, Seoul, 549 pp. (in Korean)

Pichi Sermolli, R. E. G. 1977. Tentamen pteridophytorum genera in taxonomicum ordinem redigendi. Webbia 31: 313-512.

Shing, K. S., P. S. Chiu and G. H. Yao. 1999. Hypodematiceae. In Flora Republicae Popularis Sinicae. Vol. 4(1). Shing, K. S. (ed.), Science Press, Beijing. Pp. 151-191.

Smith, A. R., K. M. Pryer, E. Schuettpelz, P. Korall, H. Schneider and P. Wolf. 2006. A classification for extant ferns. Taxon 55: 705-731.
Tryon, R. M. and A. F. Tryon. 1982. Ferns and Allied Plants, with Special Reference to Tropical America. Springer, New York, $858 \mathrm{pp}$.

Wang, F.-G., D.-M. Liu and F.-W. Xing. 2010. Two new species of Hypodematium (Hypodematiaceae) from limestone areas in Guangdong, China. Botanical Studies 51: 99-106.

Wang, R., W. Shao and L. Liu. 2014. Cytotaxonomic study of Hypodematium (Hypodematiaceae) from China. Phytotaxa 161: 101-110.

Zhang, G. and K. Iwatsuki. 2013. Hypodematium. In Flora of China, Vol. 2-3 (Pteridophytes). Wu, Z. Y., P. H. Raven and D. Y. Hong (eds.), Science Press, Beijing and Missouri Botanical Garden Press, St. Louis, MO. Pp. 535-540. 